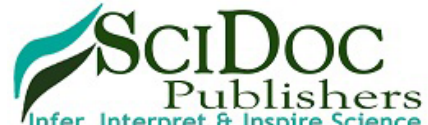

\author{
International Journal of Dentistry and Oral Science (IJDOS) \\ ISSN: $2377-8075$
}

\title{
Assessment Of Incidence Of Incomplete Cleft Palate In Patients Reported To Private Dental Hospital- An Institutional Study
}

Research Article

R Bharathi ${ }^{1}$, Senthil Murugan. $\mathrm{P}^{2 *}$

${ }^{1}$ Saveetha Dental College, Saveetha Institute of Medical and Technical Sciences (SIMATS), Saveetha University, Chennai, India.

${ }^{2}$ Associate professor, Department of Oral and Maxillofacial Surgery, Saveetha Dental College, Saveetha Institute of Medical and Technical Sciences (SIMATS), Saveetha University, 162, Poonamallee High Road, Chennai 600077, Tamil Nadu, India.

\section{Abstract}

Background: A cleft palate is an opening or split in the roof of the mouth that occurs when the tissue doesn't fuse together during development in the womb. A cleft palate often includes a split (cleft) in the upper lip (cleft lip) but can occur without affecting the lip. It is commonly called the orofacial cleft and is a birth defect. Types of cleft palate are incomplete cleft palate, complete cleft palate and submucous cleft palate.

Objective: To assess the incidence of incomplete cleft palate in patients reported to the private dental hospital.

Materials and method: Data of the patients were retrieved from the dental records. Cleft palate patients visiting the hospital were shortlisted and studied. Total study sample was 38 patients. Data was tabulated in excel and statistically analysed.

Result: The statistical analysis of this study revealed that the incidence of incomplete cleft palate patients $(56.8 \%)$ was more when compared to complete cleft palate patients $(43.2 \%)$ with a female prevalence $(61.9 \%)(\mathrm{p}>0.05$ - chi square test- not significant).

Conclusion: Within the limitations of this study, it shows that the incidence of incomplete cleft palate patients visiting the hospital were more evident and its prevalence was seen in females compared to males and patients with 1 year of age.

Keywords: Incomplete Cleft Palate; Complete Cleft Palate; Birth Defect; Orofacial Cleft; Cleft Lip.

\section{Introduction}

After clubfoot and cleft lip, cleft palate represents the third most frequently occurring congenital deformity. Among the cleft lip and palate population, the most common type is unilateral cleft lip and palate which is $46 \%$, followed by isolated cleft palate $(33 \%)$ (Strong and Buckmiller, 2001). Cleft palates affect 1 in 2000 live births worldwide regardless of race. Incidence of cleft palate is high in Asians and native Americans which is 1 in 450 live births and least in Africans which is 1 in 2000 live births [39].

Cleft palate is defined as a congenital abnormality that occurs in the secondary palate (soft and hard palate). Its occurrence may be unilateral, bilateral, complete or incomplete [24]. Cleft palate is one of the most common birth deficits in humans. It is consid- ered a multifactorial disease and both genetic and environmental factors play a role in its development $[5,25]$. Cleft lip and palate are the most common facial deformity which may involve lip only, lip and palate and palate only. The treatment depends on the site of defect and age of the patient [34].

Clefts classified grossly as unilateral type (incomplete Vs. complete), bilateral type (incomplete Vs. complete), or submucous type. In 1931, Veau classified clefts into four groups, soft palate only, cleft of soft and hard palate, unilateral cleft lip and palate, bilateral cleft lip and palate. However, this classification does not address primary palate clefts or distinguish incomplete Vs. complete clefts of the palate [9]. A cleft palate may be either complete or incomplete and is either unilateral or bilateral. A complete cleft of the entire palate includes length of the primary and secondary palate. An incomplete cleft involves only the secondary palate.

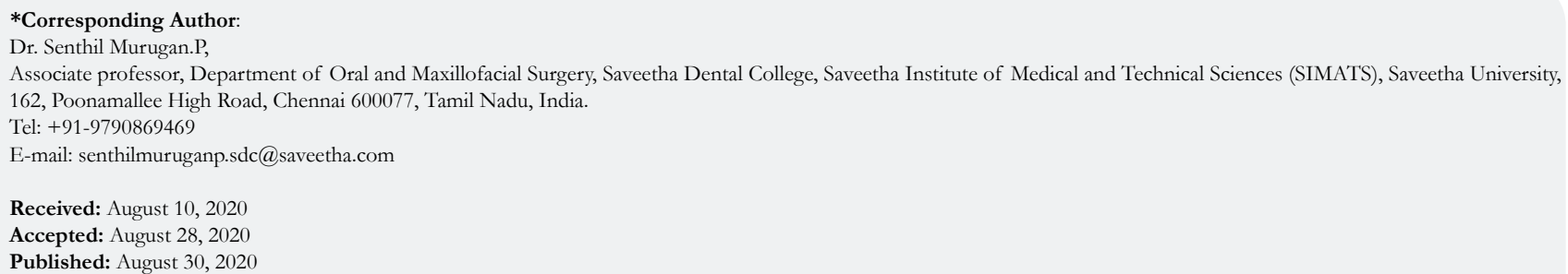

Copyright: Senthil Murugan. $\mathbf{P}^{\circ} 2020$. This is an open-access article distributed under the terms of the Creative Commons Attribution License, which permits unrestricted use, distribution and reproduction in any medium, provided the original author and source are credited. 
There are both muscular and bony deficits in submucous cleft palate [37]. But the first most commonly accepted classification was presented by Kernahan (1971) [13], it gives the shape of Y letter and includes, 1 and 4 representing the right and left side of the nasal floor, 2 and 5 representing the right and left side of the lip, 3 and 6 representing the right and left side of the paired alveolar segment, 7 represent the primary palate, 8 and 9 represents the secondary palate (Figure 8) [13].

The human palate consists of a primary and secondary palate. The primary palate includes the alveolar arch. The secondary palate includes the bony hard palate and fibromuscular soft palate. The hard palate is further divided into primary and secondary portions [3]. The soft palate consists of five pairs of muscles, the palatoglossus, palatopharyngeus, levator veli palatini, tensor veli palatini and musculus uvulae. The soft palate made of five muscles is attached as a sling to the posterior portion of the hard palate. It functions to elevate the nasopharynx, effectively closing the communication from the nasopharynx to the oropharynx [41].

Cleft palate spans many degrees of severity and can include the soft palate, hard palate and alveolus. Clefting disrupts palatal sling secondary to abnormal insertions of the muscles of the soft palate into the posterior margin of the remaining bony hard palate rather than midline raphae [21]. Neural crest theory of development states that neural crest cells, specialised embryonic cells that give rise to various connective and neural tissues of the skull and face, migrate at different rates to form the preliminary palate. If this migration fails to occur due to absence or inadequacy of related cells. Clefts and other facial abnormalities may result [10]. Fusion of the palatine shelves proceeds in a posterior direction from the incisive foramen with the fusion of the maxilla and vomer to form the bony hard palate completed by the ninth week of gestation. This process continues into the 12 th week when the soft tissues posterior the hard palate also meet to form the soft palate. Clefts of the secondary palate is due to the lack of fusion of the palatal shelves [11].

Cleft palate affecting in every 500 to 1000 births worldwide and in India every year 28600 cases are reported [31]. This study was published in 2010, since then there is no article that talks about the prevalence of cleft palate. The incidence of this defect is also increasing, so it is important to assess the incidence of cleft palate. Aim of this study was to assess the incidence of incomplete cleft palate in patients reported to the private dental hospital.

\section{Materials and Methods}

This retrospective study was conducted as a university setting which includes predominantly South Indian population. The approval for this study was provided by the institutional ethical committee (ethical approval number: SDC/SIHEC/2020/DIASDATA/0619-0320). This was a convenience sampling conducted between June 2019 to March 2020 with patients of all age groups and gender. Data was collected from the dental records, patient management records of Cleft and Craniofacial centre and studied. The sample of this study was 37 patients with cleft palate irrespective of their defect type. All the cases were approved and verified by an external reviewer and cross verification was done using a photographic method to eliminate the errors made while recording.

Inclusion criteria- patients with cleft palate visiting the hospital for treatment.

Exclusion criteria- patients without cleft palate visiting the hospital.

The independent variables were name, age, gender, ethnicity, place, complete cleft palate patients. The dependent variable was the incomplete cleft palate. The data obtained was tabulated in excel, imported to SPSS software by IBM, a statistical software with variables defined. The significance of this study was obtained using the statistical test, Chi Square and the results were interpreted.

\section{Results And Discussion}

The statistical analysis shows that the incidence of Incomplete cleft palate $(56.8 \%)$ was higher when compared to complete cleft palate patients $(43.2 \%)$ (Figure 2) visiting the hospital. In this study $35.14 \%$ were females and $21.62 \%$ were males in incomplete cleft palate(Figure 4). Therefore there was a female prevalence in the incomplete cleft palate. The age distribution of this study was as follows, 1 year $(23.4 \%)$, followed by 4 years $(14.2 \%), 10$ years (14.2\%), 6 years $(9.5 \%), 2$ years of age $(4.8 \%), 5$ years $(4.8 \%), 7$ years $(4.8 \%), 9$ years $(4.8 \%), 11$ years $(4.8 \%), 13$ years $(4.8 \%), 14$ years $(4.8 \%), 17$ years $(4.8 \%)$. Therefore, the incidence was higher in patients with 1 years of age $(23.8 \%)$ (Figure 6$)$. There was also prevalence of patients with 2 years of age in complete cleft palate patients visiting the hospital ( $\mathrm{p}>0.05$ - not significant).

The reasons for clefting may be either genetic factors such as familial factors and chromosomes or environmental factors such as smoking, alcohol, poor nutrition. Smoking and alcohol are considered as the main causes of clefts. Pregnant women with high school abuse and smoking are more prone to have babies with cleft palate. Vitamin B deficiency was the main reason for increased risk of clefts. Folic acid and zinc also considered as the main element as their supplement decreased the incidence of

Figure 1. This table shows the prevalence of incomplete cleft palate and complete cleft palate.

\begin{tabular}{|c|c|c|c|c|}
\hline & & Frequency & Valid Percent & $\begin{array}{l}\text { Cumulative } \\
\text { Percent }\end{array}$ \\
\hline \multirow[t]{3}{*}{ Valid } & Cleft palate-Incomplete & 21 & 56.8 & 56.8 \\
\hline & Cleft palate- Complete & 16 & 43.2 & 100.0 \\
\hline & Total & 37 & 100.0 & \\
\hline Total & & 38 & & \\
\hline
\end{tabular}


Figure 2. This graph shows the prevalence of incomplete and complete cleft palate. The $x$-axis represents the incomplete and complete cleft palate and y-axis represents the number of patients. Prevalence of incomplete cleft palate(56.8\%) has been observed in our study population.

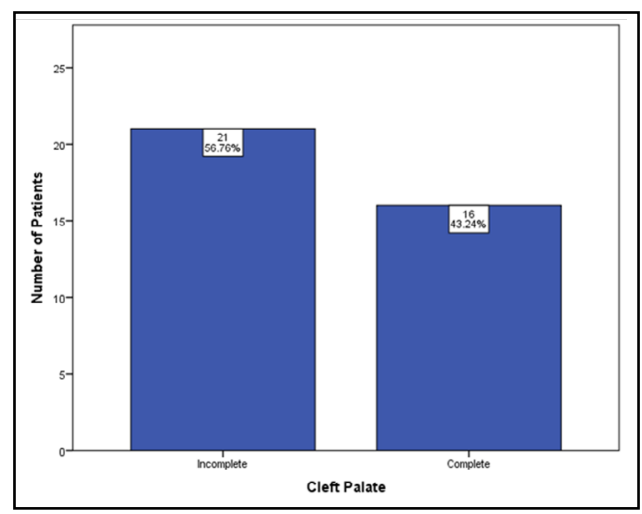

Figure 3. This table shows the prevalence of gender of this study.

\begin{tabular}{|c|c|c|c|c|}
\hline & & Frequency & Valid Percent & $\begin{array}{l}\text { Cumulative } \\
\text { Percent }\end{array}$ \\
\hline \multirow[t]{3}{*}{ Valid } & Female & 18 & 48.6 & 48.6 \\
\hline & Male & 19 & 51.4 & 100.0 \\
\hline & Total & 37 & 100.0 & \\
\hline Total & & 38 & & \\
\hline
\end{tabular}

Figure 4. This graph represents the association of gender and cleft palate. The $x$-axis represents the gender and $y$-axis represents the number of patients. The blue colour represents the incomplete cleft palate and green colour represents the complete cleft palate. There is no significant association of gender and cleft palate ( $\mathrm{p}>\mathbf{0 . 0 5}$ - chi-square- not significant). In our study we observed that incomplete cleft palate is more prevalent among females and the incidence of complete cleft palate is more among males.

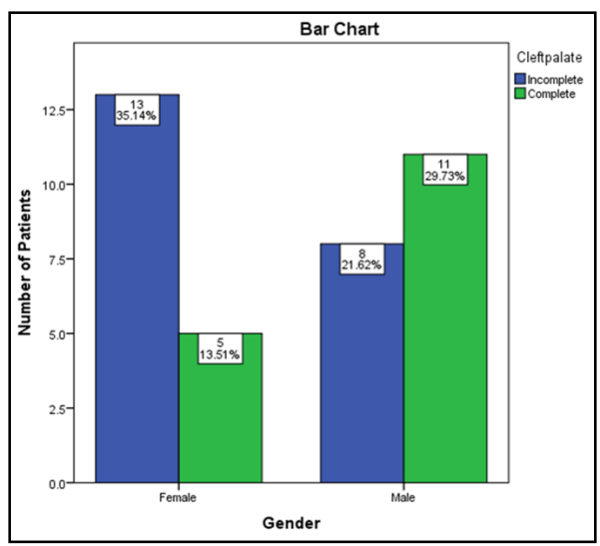

Figure 5. This table shows the prevalence of age of this study.

\begin{tabular}{|c|c|c|c|c|}
\hline & & Frequency & Valid Percent & $\begin{array}{l}\text { Cumulative } \\
\text { Percent }\end{array}$ \\
\hline \multirow{16}{*}{ valid } & 0 & 3 & 8.1 & 8.1 \\
\hline & 1 & 7 & 18.9 & 27.0 \\
\hline & 2 & 6 & 16.2 & 43.2 \\
\hline & 3 & 1 & 2.7 & 45.9 \\
\hline & 4 & 5 & 13.5 & 59.5 \\
\hline & 5 & 1 & 2.7 & 62.2 \\
\hline & 6 & 3 & 8.1 & 70.3 \\
\hline & 7 & 1 & 2.7 & 73.0 \\
\hline & 9 & 1 & 2.7 & 75.7 \\
\hline & 10 & 3 & 8.1 & 83.8 \\
\hline & 11 & 2 & 5.4 & 89.2 \\
\hline & 13 & 1 & 2.7 & 91.9 \\
\hline & 14 & 1 & 2.7 & 94.6 \\
\hline & 15 & 1 & 2.7 & 97.3 \\
\hline & 17 & 1 & 2.7 & 100.0 \\
\hline & Total & 37 & 100.0 & \\
\hline
\end{tabular}


Figure 6. This graph represents the association of age and cleft palate. The $x$-axis represents the age and the y-axis represents the number of patients. The blue colour represents the incomplete cleft palate and green colour represents the complete cleft palate. There is no significant association of age and cleft palate ( $\mathbf{>} \mathbf{0 . 0 5}$ - chi-square- not significant). There is a prevalence in patients of 1 years of age in incomplete cleft palate and prevalence in patients of 2 years of age in complete cleft palate.

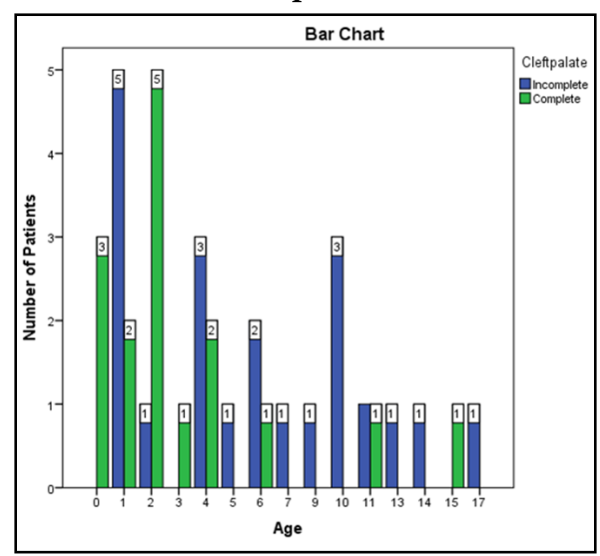

Figure 7. This table shows the results of the statistical analysis of cleft palate patients based on age and gender. This shows that the study is statistically not significant with $\mathrm{p}$ value greater than 0.05 .

\begin{tabular}{|l|l|l|l|}
\hline \multicolumn{5}{|l|}{ ASSOCIATION BETWEEN GENDER AND CLEFT PALATE (complete and incomplete) } \\
\hline & Value & df & $\begin{array}{l}\text { Asymptotic Significance } \\
\text { (2-sided) }\end{array}$ \\
\hline Pearson Chi-Square & $3.416^{\circ}$ & 1 & .065 \\
\hline Likelihood Ratio & 3.481 & 1 & .062 \\
\hline $\begin{array}{l}\text { Linear-by-Linear } \\
\text { Association }\end{array}$ & 3.324 & 1 & .068 \\
\hline N of Valid Cases & 37 & \multicolumn{2}{l|}{} \\
\hline ASSOCIATION BETWEEN AGE AND CLEFT PALATE (complete and incomplete) & \\
\hline & Value & df & $\begin{array}{l}\text { Asymptotic Significance } \\
\text { (2-sided) }\end{array}$ \\
\hline Pearson Chi-Square & $18.141^{\text {a }}$ & 14 & .200 \\
\hline Likelihood Ratio & 23.511 & 14 & .052 \\
\hline $\begin{array}{l}\text { Linear-by-Linear } \\
\text { Association }\end{array}$ & 3.856 & 1 & .050 \\
\hline N of Valid Cases & 37 & \multicolumn{2}{l}{} \\
\hline
\end{tabular}

Figure 8. Kernahans classification of cleft palate(1971). 1 and 4 represent the right and left side of the nasal floor, 2 and 5 represent the right and left side of the lip, 3 and 6 represent the right and left side of the paired alveolar segment, 7 represent the primary palate, 8 and 9 represent the secondary palate.

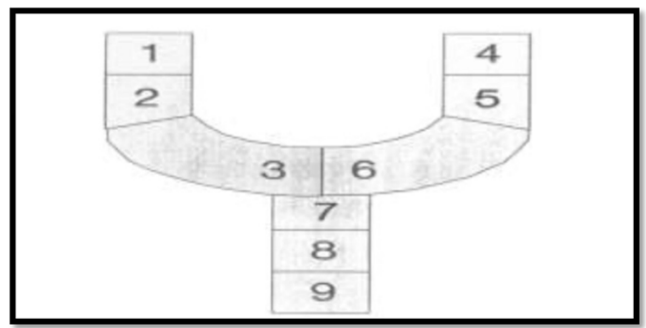

clefts [23]. Cleft palate can result from some medications such as corticosteroids, retinoid drugs causing cleft in infants because of exposing pregnant women to these drugs. Exposure to chemicals and solvents can cause clefts. Genetic factors include family history which is considered as one of the main reasons to cause cleft lip and palate. The cleft palate and lip is associated with many syndromes [14] such as Pierre Robin syndrome, Sticklers syndrome, Treacher Collins syndrome, Apert syndrome, Hemifacial microsomia, ectodermal dysplasia, velocardiofacial syndrome. Non syndrome cleft palate can also occur which is related to Trisomy 13, Trisomy 21 [1-3] and Trisomy 18 [22].

Common problems associated with cleft palate are speech problem, hearing problem, ear infection, dental problems, feeding problems, nutritional problems, cosmetic problems and psychological problems [19]. Speech problem is due to the inability of the soft palate to move upward to provide a contact with nasal cavity resulting in passing of air through the nose instead of oral cavity. Hearing problems are due to the abnormal action of Eus- tachian tube opening by tensor veli palatini and levator veli palatini muscles leading to lack of ventilation to the middle ear cavity and accumulation of fluid leading to ear infections. Dental problems include size, shape and position of teeth, delayed eruption of permanent teeth and delay of formation of the same [4]. Feeding problems are due to their inability of sucking either their mother's nipple or bottle. Therefore leading to nutritional problems,. In this case disposable syringe, spoon and cup and prosthetic obturator device can be used. They experience problems in production of labial sounds, difficulty when they try to make contact between upper and lower lips, cosmetic problems. Cleft palate and lip patients develop psychological problems like depression,anxiety [1, $2,15]$ and lack of esteem [36].

Normally the development of the palate depends on proper growth, migration, apoptosis and differentiation of these cells and occurs in three major stages such as vertical growth of the shelves down toward the sides of the tongue, elevation of the palatal shelves to acquire a horizontal position as the mandible 
lengthens and fusion of the palatal shelves to form the transient midline epithelial seam [32] Cleft palate can be due to an error in any of these stages. The defects can be grouped into five categories such as failure of palatal shelf formation, fusion of palatal shelf elevation, failure of palatal shelves to meet post- elevation and persistence of the medial edge epithelium [6]. Children born with oral clefts have been shown to have high mortality rates especially in the presence of other defects. Most common cause is due to congenital malformations of the heart, primary brain cancer. Breast, colorectal, stomach, prostate and uterine cancers [20] are to be the most common among oral clefts [5]. Consanguineous relationships were seen in $56.8 \%$ patients with cleft palate and it is a major factor causing clefts [30].

Multidisciplinary team is essential to manage the many facets affected by orofacial clefting [40]. All patients were treated under general anaesthesia [27]. May require fibreoptic intubation as in PRS. Training regarding biomedical waste management is important [17]. Primary outcome measures were operating time and intraoperative blood loss, while the secondary outcome measures were needed for blood transfusion, surgical field assessment and duration of hospitalization [7]. Non- surgical treatment of the cleft palate is attempted with Prosthodontics devices designed to correct the incompetence. This is indicated to patients who are at high risk for surgery, those in whom surgery has failed. The most common surgical techniques for the repair of soft palate are furlow double opposing z plasty and intravelar veloplasty. Hard palate surgeries are Von Langenbeck palatoplasty [33]. The most common complications [1] followed by surgical repair [1,26] of cleft palate include palatal fistula, persistent velopharyngeal insufficiency and sleep apnea $[12,40]$. Post operative pain can be controlled by prescribing NSAIDS like Ketorolac since the duration of analgesia is longer [29]. Since surgical dental procedures are common and risk for cardiac diseases is on the rise, use of antibiotic prophylaxis before the start of treatment is highly recommended [18]. BTX injections have proven to be useful in assisting post operative wound healing [16].

In the current study, there was a prevalence of incomplete cleft palate patients $(56.8 \%)$ compared to complete cleft palate patients (43.2\%). According to Yilmaz, the most common oro facial cleft is unilateral cleft lip and palate(left side), followed by cleft palate [42]. Sivertsen stated that the more severe the cleft lip, the more likely the baby had cleft palate [35]. Srinivas Gosla listed the prevalence of clefts as distribution of the type of cleft in which $33 \%$ had cleft lip, 64\% had cleft lip and palate, $2 \%$ had cleft palate and $1 \%$ had rare craniofacial clefts and the birth rate of clefts is 1.09 for every 1000 live births [31]. These studies show the prevalence of cleft palate among all other clefts but there are no studies that compare the prevalence among the types of cleft palate.

In relation to the occurrence of incomplete cleft palate based on gender, maximum occurrences were noticed in female gender (35.14\%) and male gender (21.62\%). This is in concordance with the study done by Derijcke, whose epidemiological studies show the incidence of cleft palate group in several regions of the world with prevalence of girls [8]. Yilmaz also compared the incidence of cleft palate based on gender and stated the females are more prone to have cleft palate [42]. According to Siversten, girls are more likely to have severe clefts. Cleft palate is more commonly reported in females than males [35]. This is because the female palate is known to close 1 week later than male palate increas- ing the risk of cleft palate formation. Female sex hormones may play a role in increased clefting for both lips and palate [43]. Incidence of oral-facial clefting shows ethnic variation. Generally it is thought that populations of Native North American or Asian have the highest incidence, Caucasian populations have intermediate incidence and African populations have the lowest incidence [31].

\section{Limitations}

Drawback of this study is that the sample size is small and inadequate. Duration of this study included only the samples from some parts of south India. To ascertain the results of this study and to increase the significance level, sample size should be increased and the geographic coverage should extend at least to the most parts of South India. Future scope of this study is to conduct it as a multicentered study and increase the geographic limitation. The awareness for the causes and treatment of this condition should be created among the general population [28].

\section{Conclusion}

Within the limitations of this study, it is found that there is a prevalence in incomplete cleft palate patients with female prevalence and at the age group of 1 year in the private dental hospital.

\section{References}

[1]. Abhinav RP, Selvarasu K, Maheswari GU, Taltia AA. The Patterns and Etiology of Maxillofacial Trauma in South India. Ann Maxillofac Surg. 2019 Jan-Jun;9(1):114-117. Pubmed PMID: 31293938.

[2]. Sweta VR, Abhinav RP, Ramesh A. Role of Virtual Reality in Pain Perception of Patients Following the Administration of Local Anesthesia. Ann Maxillofac Surg. 2019 Jan-Jun;9(1):110-113. Pubmed PMID: 31293937.

[3]. Berkowitz S. 'Complete Bilateral Cleft Lip and Palate'.Cleft Lip and Palate. 99-191. doi: 10.1007/3-540-30020-1_9.

[4]. Beumer III J, Marunick MT, Esposito SJ. Maxillofacial rehabilitation: prosthodontic and surgical management of cancer-related, acquired, and congenital defects of the head and neck. Quintessence Pub. 2011;276.

[5]. Bille C, Winther JF, Bautz A, Murray JC, Olsen J, Christensen K. Cancer risk in persons with oral cleft--a population-based study of 8,093 cases. Am J Epidemiol. 2005 Jun 1;161(11):1047-55. Pubmed PMID: 15901625.

[6]. Chai Y, Maxson RE Jr. Recent advances in craniofacial morphogenesis. Dev Dyn. 2006 Sep;235(9):2353-75. Pubmed PMID: 16680722.

[7]. Christabel A, Anantanarayanan P, Subash P, Soh CL, Ramanathan M, Muthusekhar MR, et al. Comparison of pterygomaxillary dysjunction with tuberosity separation in isolated Le Fort I osteotomies: a prospective, multi-centre, triple-blind, randomized controlled trial. Int J Oral Maxillofac Surg. 2016 Feb;45(2):180-5. Pubmed PMID: 26338075.

[8]. Derijcke A, Eerens A, Carels C. The incidence of oral clefts: a review. Br J Oral Maxillofac Surg. 1996 Dec;34(6):488-94. Pubmed PMID: 8971440.

[9]. 'Division Palatine. By Veau Victor. With the Collaboration of Mme. S. Borel. Masson et Cie. Price 140 francs. - Traitement du Bec-de-Lievre Unilateral. By Veau Victor. Massen et Cie. Price 30 Francs'. The Journal of Laryngology \& Otology.1932; 294-294. doi: 10.1017/s0022215100037257.

[10]. Fraser FC. Workshop on embryology of cleft lip and cleft palate. Teratology. 1968 Aug;1(3):353-8. Pubmed PMID: 5759553.

[11]. Goodacre T, Swan MC. Cleft lip and palate: current management. Paediatrics and child health. 2008 Jun 1;18(6):283-92.

[12]. Jesudasan JS, Wahab PU, Sekhar MR. Effectiveness of $0.2 \%$ chlorhexidine gel and a eugenol-based paste on postoperative alveolar osteitis in patients having third molars extracted: a randomised controlled clinical trial. $\mathrm{Br} \mathrm{J}$ Oral Maxillofac Surg. 2015 Nov;53(9):826-30. Pubmed PMID: 26188932.

[13]. Kernahan DA. The striped Y--a symbolic classification for cleft lip and palate. Plast Reconstr Surg. 1971 May;47(5):469-70. Pubmed PMID: 5574216.

[14]. Kumar S. Knowledge, attitude and awareness of dental undergraduate students regarding HIV/AIDS patients '. Asian Journal of Pharmaceutical and Clinical Research. 2017:175.

[15]. Kumar S. Relationship between dental anxiety and pain experience during 
dental extractions. Asian Journal of Pharmaceutical and Clinical Research. 2017;10(3):458-62.

[16]. Kumar S. The emerging role of botulinum toxin in the treatment of orofacial disorders: Literature update. Asian Journal of Pharmaceutical and Clinical Research. 2017;10(9):21-9.

[17]. Kumar S, Rahman RE. Knowledge, awareness, and practices regarding biomedical waste management among undergraduate dental students. Asian Journal of Pharmaceutical and Clinical Research. 2017;10(8):341.

[18]. Kumar S, Sneha S. Knowledge and awareness regarding antibiotic prophylaxis for infective endocarditis among undergraduate dental students. Asian Journal of Pharmaceutical and Clinical Research. 2016;154.

[19]. Kummer AW. Speech evaluation for patients with cleft palate. Clin Plast Surg. 2014 Apr;41(2):241-51. Pubmed PMID: 24607192.

[20]. Marimuthu M, Andiappan M, Wahab A, Muthusekhar MR, Balakrishnan A, Shanmugam S. Canonical Wnt pathway gene expression and their clinical correlation in oral squamous cell carcinoma. Indian J Dent Res. 2018 MayJun;29(3):291-297. Pubmed PMID: 29900911.

[21]. Matsune S, Sando I, Takahashi H. Insertion of the tensor veli palatini muscle into the eustachian tube cartilage in cleft palate cases. Ann Otol Rhinol Laryngol. 1991 Jun;100(6):439-46. Pubmed PMID: 2058982.

[22]. Mosahebi A, Kangesu L. Cleft lip and palate. Surgery (Oxford). 2004 Sep 1;22(9):218-22.

[23]. Mossey PA, Little J, Munger RG, Dixon MJ, Shaw WC. Cleft lip and palate. The Lancet. 2009 Nov 21;374(9703):1773-85.

[24]. Muhamad A. Cleft lips and palates: the roles of specialists. Minerva Pediatr. 2011 Jun;63(3):227-32. Pubmed PMID: 21654602.

[25]. Murray JC, Schutte BC. Cleft palate: players, pathways, and pursuits. J Clin Invest. 2004 Jun;113(12):1676-8. Pubmed PMID: 15199400.

[26]. Packiri S, Gurunathan D, Selvarasu K. Management of Paediatric Oral Ranula: A Systematic Review. J Clin Diagn Res. 2017 Sep;11(9):ZE06-ZE09. Pubmed PMID: 29207849

[27]. Patil SB, Durairaj D, Suresh Kumar G, Karthikeyan D, Pradeep D. Comparison of Extended Nasolabial Flap Versus Buccal Fat Pad Graft in the Surgical Management of Oral Submucous Fibrosis: A Prospective Pilot Study. J Maxillofac Oral Surg. 2017 Sep;16(3):312-321. Pubmed PMID: 28717289.

[28]. Patturaja K, Pradeep D. Awareness of Basic Dental Procedure among General Population. Research Journal of Pharmacy and Technology. 2016 Sep $1 ; 9(9): 1349$

[29]. Rao TD, Kumar MS. Analgesic efficacy of paracetamol vs ketorolac after dental extractions. Research Journal of Pharmacy and Technology. 2018 Aug $1 ; 11(8): 3375-9$.
[30]. Ravichandran K, Shoukri M, Aljohar A, Shazia NS, Al-Twaijri Y, Al Jarba I. Consanguinity and occurrence of cleft lip/palate: a hospital-based registry study in Riyadh. Am J Med Genet A. 2012 Mar;158A(3):541-6. Pubmed PMID: 22302702.

[31]. Reddy SG, Reddy RR, Bronkhorst EM, Prasad R, Ettema AM, Sailer HF, Bergé SJ. Incidence of cleft Lip and palate in the state of Andhra Pradesh, South India. Indian J Plast Surg. 2010 Jul;43(2):184-9. Pubmed PMID: 21217978.

[32]. Rizell S, Alhakim Z, Mark H, Naoumova J. Predictive factors for canine position in patients with unilateral cleft lip and palate. Eur J Orthod. 2020 May 27:cjaa034 pubmed PMID: 32459854.

[33]. Salyer KE, Sng KW, Sperry EE. Two-flap palatoplasty: 20-year experience and evolution of surgical technique. Plast Reconstr Surg. 2006 Jul;118(1):193204. Pubmed PMID: 16816695.

[34]. Shkoukani MA, Chen M, Vong A. Cleft lip - a comprehensive review. Front Pediatr. 2013 Dec 27;1:53. Pubmed PMID: 24400297.

[35]. Sivertsen Å, Wilcox A, Johnson GE, Åbyholm F, Vindenes HA, Lie RT. Prevalence of major anatomic variations in oral clefts. Plast Reconstr Surg. 2008 Feb;121(2):587-595. Pubmed PMID: 18300979.

[36]. Snyder M. Early Feeding Experiences of Families Whose Children Were Born with Cleft Lip andor Palate: A Rural Perspective.

[37]. Sperber GH, Sperber SM. Embryogenetics of cleft lip and palate. InCleft lip and palate 2013 (pp. 3-33). Springer, Berlin, Heidelberg.

[38]. Strong EB, Buckmiller LM. Management of the cleft palate. Facial plastic surgery clinics of North America. 2001 Feb 1;9(1):15-25.

[39]. Vanderas AP. Incidence of cleft lip, cleft palate, and cleft lip and palate among races: a review. Cleft Palate J. 1987 Jul;24(3):216-25. pubmed PMID: 3308178.

[40]. Vijayakumar Jain S, Muthusekhar MR, Baig MF, Senthilnathan P, Loganathan S, Abdul Wahab PU, et al. Evaluation of Three-Dimensional Changes in Pharyngeal Airway Following Isolated Lefort One Osteotomy for the Correction of Vertical Maxillary Excess: A Prospective Study. J Maxillofac Oral Surg. 2019 Mar;18(1):139-146. doi: 10.1007/s12663-018-1113-4. Epub 2018 May 8. Pubmed PMID: 30728705.

[41]. Wexler A. Anatomy of the head and neck. InFundamentals of Maxillofacial Surgery 1997 (pp. 53-113). Springer, New York, NY.

[42]. Yılmaz HN, Özbilen EÖ, Üstün T. The Prevalence of Cleft Lip and Palate Patients: A Single-Center Experience for 17 Years. Turk J Orthod. 2019 Sep;32(3):139-144. pubmed PMID: 31565688.

[43]. C Yu J, Hilton R, Gerry Magana R. Pierre robin sequence. Current Pediatric Reviews. 2011 Feb 1;7(1):15-9. 